\title{
Bivalve Mariculture in Two - Way Interaction with Phytoplankton: A Review of Feeding Mechanism and Nutrient Recycling
}

\author{
Rasheed Olatunji MORUF ${ }^{1 *}$, Gabriel Femi OKUNADE², Owoyemi Wahab ELEGBELEYE ${ }^{3}$ \\ ${ }^{1}$ Department of Fisheries and Aquaculture, Bayero University, Kano, Kano State, Nigeria \\ ${ }^{2}$ Department of Biological Sciences, Yaba College of Technology, Lagos State, Nigeria \\ ${ }^{3}$ Department of Marine Sciences, University of Lagos, Akoka, Lagos State, Nigeria \\ *corresponding author: tunjimoruf@gmail.com
}

Bulletin UASVM Animal Science and Biotechnologies 77(2)/2020

ISSN-L 1843-5262; Print ISSN 1843-5262; Electronic ISSN 1843-536X

DOI:10.15835/buasvmcn-asb: 2020.0010

\begin{abstract}
Bivalve mariculture is a type of molluscan farming done in open seawater on racks, rafts or longlines where naturally occurring phytoplankton serves as a key food item, introduced into the enclosures with the normal circulation of seawater. Increasingly, the reverse trophic interaction is being recognized; dissolved inorganic and organic waste compounds released by metabolically active bivalves can supply phytoplankton with nutrient and energy requirements for their growth. This two-way interaction can be viewed as a type of community symbiosis developed over long evolutionary timescales. The extent to which this affects overall nutrient budgets and thus primary production is related to the system flushing rate and residence time. Here we reviewed the feeding mechanism and nutrient recycling activities of bivalve and also emphasized the role of phytoplankton as a key nutritional live feed in sustainable bivalve mariculture. Bivalves influence nutrient dynamics through direct excretion and indirectly through microbial mediated remineralisation of their organic deposits in the sediments. The quantitative knowledge of bivalve - phytoplankton trophic interactions in coastal waters will inform bivalve mariculture development to effectively serve the needs of both seafood production and ecosystem restoration.
\end{abstract}

Keywords: bottom-feeder, food web, microalgae, mollusc farming, symbiosis.

\section{Introduction}

Mollusks are important resources that contribute considerable economic value to the world's fisheries. The global production of marine mollusk for human consumption is more than 17 million tonnes in the year 2018, with China as the major producer with relatively highest percentage of production (FAO, 2020). In terms of mariculture (disregarding freshwater production), mollusc production exceeds finfish production value by over 900-fold (Mau \& Jha, 2018). As a concept, mariculture is the rearing of aquatic organisms under controlled or semi controlled condition in coastal and offshore waters where salinity is maximal and not subject to significant daily or seasonal variation. Mariculture has more recently become an important source of bivalve, which is the focus of this review.

Bivalves as a group have no head and they lack some usual molluscan organs like the radula and the odontophore (Romano et al., 2014). They include the clams, oysters, cockles, mussels, scallops, and numerous other families that live in saltwater, as well as a number of families that live in freshwater. Bivalve mariculture is a type of molluscan farming done in open seawater 
on racks, rafts or longlines. The commercial importance of bivalve mariculture include but not limited to food security, pearl production and lime manufacture. As listed by Narasimham (2005), popular culture species of oysters include Crassostrea madrasensis, C. gryphoides, C. rivularis and Saccostrea cucullata; culture species of mussel are Perna viridis and $P$. indica; culture species of clams are Villorita cyprinoids, Paphia malabarica, Meritrix casta and Anadara granosa while culture species of scallops are Chlamys barrei, $C$. nobills, Placopecten magellanicus and Argopecten irradians.

One of the factors that influence bivalve growth in both natural populations and mariculture conditions is availability and quality of food. Traditionally, phytoplankton was considered as primary food source for bivalves (Gosling, 2003). However, a number of studies pointed out that energy is also derived from other food sources such as bacteria, detritus and even zooplankton (Lehane \& Davenport, 2006). Through filter feeding, bivalves play important role in marine ecosystems by controlling abundances of primary producers, zooplankton and larval stages of other marine species. By this process, bivalves have great influence in energy and nutrient flux between benthic and pelagic communities (Arapov et al., 2010).

The two-way interaction between bivalve mariculture and phytoplankton fundamentally involve feeding and nutrient recycling activities of bivalve molluscs, which tend to sustain primary production locally. This paper aimed to give an overview of current understanding on bivalve's feeding mechanism and to emphasize the role of phytoplankton as a key nutritional live feed in bivalve mariculture, by reviewing the worldwide literature through Internet search engines, textbooks and theses. Literatures obtained were analyzed in pros and relevant cited figure and headings were adopted.

\section{Phytoplankton as a Basic Element in a Classical Food Web}

Unlike terrestrial environments, marine environments have biomass pyramids which are inverted at the base. In particular, the biomass of consumers (copepods, krill, bivalve) is larger than the biomass of primary producers (Arapov et al., 2010). This happens because the ocean's primary producers are tiny phytoplankton, which grow and reproduce rapidly, so a small mass can have a fast rate of primary production (Gao \& Campbell, 2014). Phytoplankton are the autotrophic (selffeeding) components of the plankton community and a key part of oceans, seas and freshwater basin ecosystems. According to Pal and Choudhury (2014), phytoplankton are free-floating photosynthetic aquatic microorganisms, which move from one place to another, either actively by their locomotor organs (flagella) or passively by water currents. Today, the contribution of phytoplankton to the biosphere continues to be unique because this group largely contributes to the renewal of the atmospheric oxygen and acts as a tremendous sink for $\mathrm{CO}_{2}$, which is used for the synthesis of organic compounds through photosynthesis (Nelson et al., 1995). While accounting for less than $1 \%$ of Earth's biomass, phytoplankton is responsible for more than $50 \%$ annual net biomass production (Bowler et al., 2010).

Phytoplankton differentiate from other planktonic taxa by the presence of photosynthetic membranes. This makes them produce biomass by autotrophically converting naturally occurring carbon into protoplasm. In this way, phytoplankton function as the foundation of the marine food web by supporting all other life in the ocean. Food webs are built from food chains. All forms of life in the sea have the potential to become food for another life form. In the ocean, a food chain typically starts with energy from the sun powering phytoplankton, and follows a course shown in Figure 1.

Phytoplankton community supports the base of the natural food chain depending on which the natural fauna including the fish populations can survive (Napiórkowska-Krzebietke, 2017). A simplified classical food web in an aquatic ecosystem comprises phytoplankton as staple food for zooplankton, and further zooplankton as food for planktivorous fish, which in turn are food for predatory fish. A 2017 study estimated the nutritional value of natural phytoplankton in terms of carbohydrate, protein and lipid across the world ocean using ocean-colour data from satellites, and found the calorific value of phytoplankton to vary considerably across different oceanic regions and between different times of the year (Roy, 2018).

\section{Biologically Active Ingredients of Phytoplankton}

Phytoplankton produce valuable compounds that include crucial phytonutrients and biologically active ingredients, e.g. fatty acids, amino acids, 


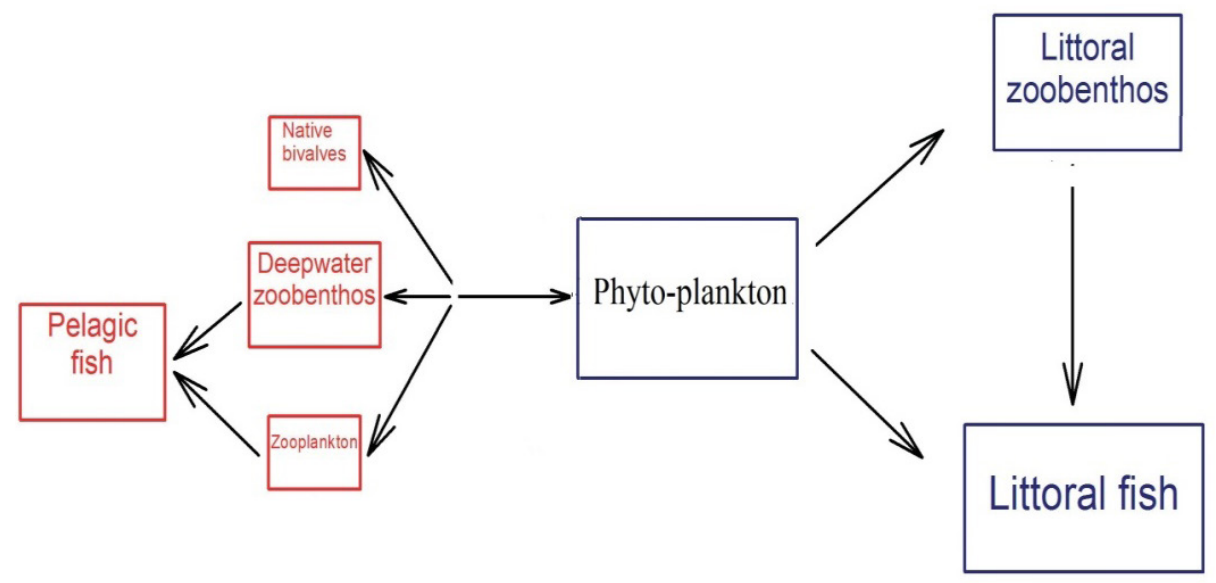

\section{Pelagic food web}

Littoral food web

Figure 1. Summary of phytoplankton as a basic element in a classical food web

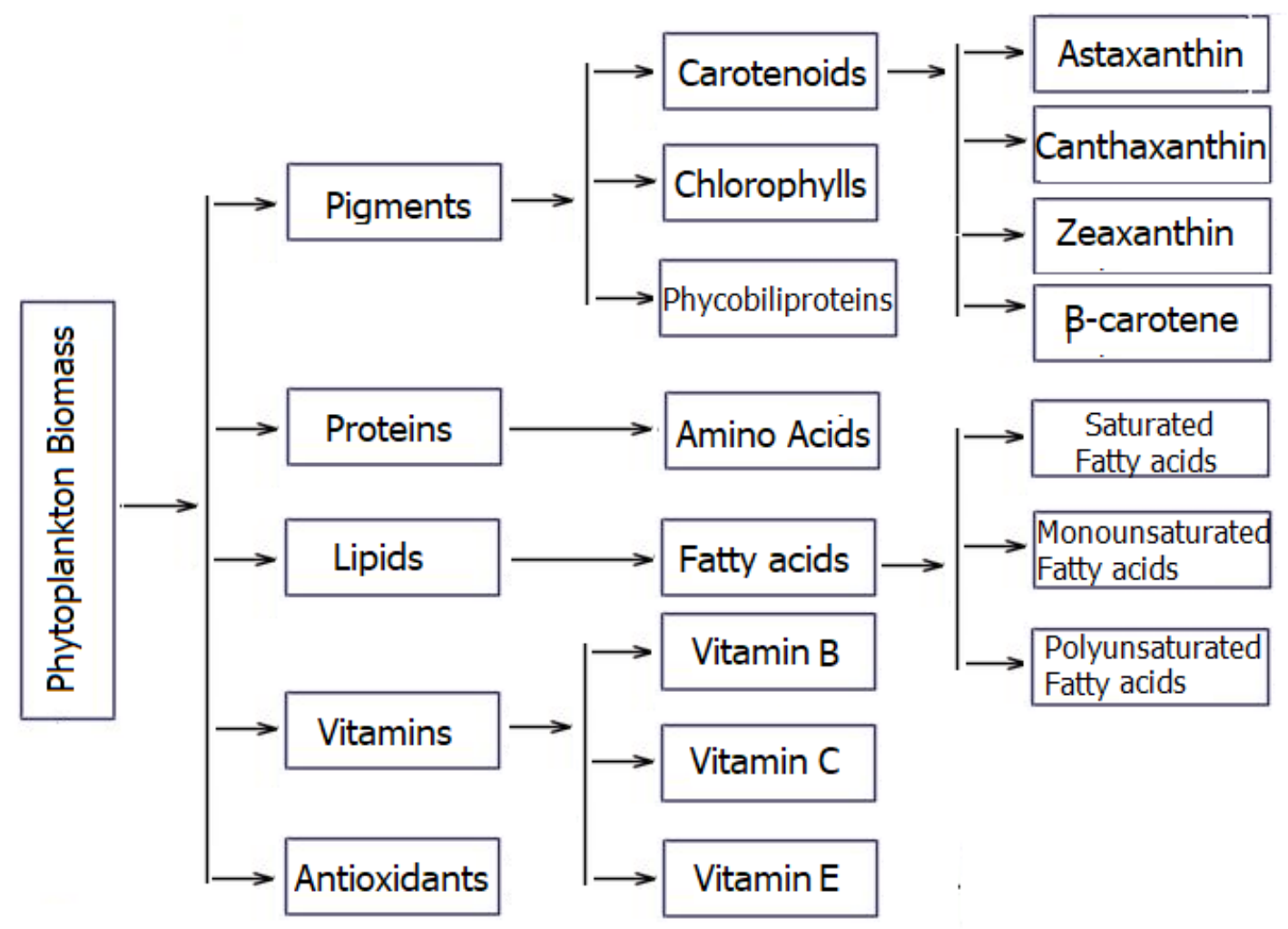

Figure 2. Notable biomolecules from phytoplankton biomass

carotenoids, chlorophyll, vitamins, antioxidants (Figure 2). Thus, thorough nutritional and toxicological investigations have validated the suitability of algal biomass for use as a high-grade feed in the production of bivalve molluscs (Kovač et al.,
2013). These bio-compounds play physiological roles that allow cells to deal with changes of the environmental constrains. For example, the diversity of light-harvesting pigments allows efficient 
photosynthesis at different depths in the seawater column (Heydarizadeh et al., 2013).

Regarding lipids in aquatic ecosystems, phytoplankton can predominantly synthesize polyunsaturated fatty acids (PUFA), which in turn are mainly consumed by zooplankton and benthic invertebrates. Different groups of phytoplankton such as cryptophytes, diatoms, dinophytes and euglenophytes, can synthesize high amounts of highly unsaturated fatty acids (HUFA - a subset of PUFA), which are transferred and accumulated at progressively higher levels in aquatic organisms (Gladyshev et al., 2009; Koyande et al., 2019). Thus, an aquatic ecosystem offers the principal dietary sources of $n-3$ HUFA for all aquatic animals. Generally, the phytoplankton fatty acids are composed of saturated fatty acid (SAFA), monounsaturated fatty acids (MUFA) and polyunsaturated fatty acids (PUFA) (including also their derivatives HUFA) (Kovač et al., 2013). However, the traces of phytoplankton in an aquatic food web remain as phytonutrients, primarily providing PUFA, e.g. eicosapentaenoic acid (EPA), arachidonic acid (AA) and docosahexaenoic acid (DHA), usually supplied at a higher-level in consumers (Arab-Tehrany et al., 2012). Additionally, environmental conditions significantly influence the metabolic processes, while the quantity and quality of essential micro and macroelements in food and water are of paramount importance for bivalve (Terech-Majewska et al., 2016). Lipids (especially PUFA), in turn, are the nutritional factors and essential components in modifying the animal growth, health and even reproduction (Desvilettes and Bec, 2009). Therefore, phytoplankton are broadly recognized in bivalve mariculture as a key nutritional live food owing to its high amounts of phytonutrients and biologically active ingredients.

Moving from gross measures of food quantity to food quality, there is a consensus that high protein contents in phytoplankton cells, and consequently in seston of coastal waters, generally are able to provide nutritional needs of bivalves for dietary protein (Arab-Tehrany et al., 2012). In contrast, specific lipids, especially long - chain, PUFA and certain sterols, may be limiting in phytoplankton and seston food sources of bivalves (Pachiappan et al., 2019). These lipids are required as structural membrane components in bivalve cells, rather than for their energy content (Delaporte et al., 2005). Dietary PUFAs and sterols are de- pendent on both the energy status and the taxonomic composition of the phytoplankton community, with some microalgal classes being devoid of these compounds (e.g., chlorophytes have no PUFAs longer than 18 carbons, but 20 - and 22 - carbon PUFAs are considered to be essential) (Kovač et al., 2013).

\section{Feeding Mechanism of Bivalve}

Based on the mechanism of food collection, bivalves can be suspension-feeders or depositfeeders, or even utilize both feeding methods (Arapov et al., 2010). Although there are some differences in particles processing, basic mechanism remains the same. Once particles entered the mantle cavity, they are transferred along the ctenidium to the labial palps, which are considered as a main site of particle selection (Arapov et al., 2010). After selection on the palial organs, some particles are rejected as pseudofeces while other are ingested (Gofas, 2012). When particles through oesophagus enter the stomach, mechanical and enzymatic decomposition of ingested food begins. Rotating crystalline style mechanically breaks large particles while enzymes released from the style start to decompose organic particles (Zanzerl, 2015). Food particle selection is based on particle size, shape, nutritive value or chemical component on the surface of the particle (Lehane \& Daven-port, 2006; Yahel et al., 2009).

In the Filibranchia and Eulamellibranchia, water is drawn into the shell from the posterior ventral surface of the animal, passes upwards through the gills, and doubles back to be expelled just above the intake (Taylor \& Glover, 2006). In burrowing species, there may be two elongated, retractable siphons reaching up to the seabed, one each for the inhalant and exhalant streams of water. The gills of filter-feeding bivalves are known as ctenidia and have become highly modified to increase their ability to capture food (Arapov et al., 2010). For example, the cilia on the gills, which originally served to remove unwanted sediment, has become adapted to capture food particles, and transport them in a steady stream of mucus to the mouth (Cranford et al., 2011). The filaments of the gills are also much longer than those in more primitive bivalves, and are folded over to create a groove through which food can be transported (Taylor and Glover, 2006). The structure of the gills varies considerably, and can serve as a useful means for classifying bivalves into groups. 
A few bivalves, such as the granular poromya (Poromya granulata), are carnivorous, eating much larger prey than the tiny microalgae consumed by other bivalves (Krylova, 2001). In these animals, the gills are relatively small, and form a perforated barrier separating the main mantle cavity from a smaller chamber through which the water is exhaled. Muscles draw water in through the inhalant siphon that is modified into a cowl-shaped organ, sucking in small crustaceans and worms at the same time. The siphon can be retracted quickly and inverted, bringing the prey within reach of the mouth while the gut is modified so that large food particles can be digested (Ward \& Shumway, 2004).

As the dietary energy available to a feeding bivalve is modified by the carbon status of the phytoplankton, feeding over the course of the day will present bivalves with a range of energy contents within ingested food (Krylova, 2001). Similarly, the protein, hence nitrogen, content of phytoplankton is dependent on the availability of this nutrient and sufficient energy for anabolic protein synthesis (Geider \& La Roche, 2002). The feeding habits and/or preferences of different bivalve species vary immensely. However, the composition of diets ingested by the first larval stages is quite similar and, in turn, very important in assessment of the feeding conditions and opportunities to satisfy food requirements in aquatic ecosystems (Napiórkowska-Krzebietke, 2017). The composition of a diet is usually determined based on an analysis of the entire gut content, and a percentage-based method is used to express the results.

\section{Nutrient Recycling Activities of Bivalves}

Benthic suspension feeders, such as many species of bivalve molluscs, influence the nutrient and organic coupling of benthic and pelagic systems through their ability to filter a wide size range of particles and deposit organic wastes that sink to the bottom (bio-deposition) (Wikfors, 2011). Suspension-feeding bivalves perform this function in a range of habitats and physiographic conditions where they filter out and deposit significant amounts of suspended material, as well as excrete dissolved nutrients. Bivalves influence nutrient dynamics through direct excretion and indirectly through microbially mediated remineralization of their organic deposits in the sediments (McKindsey et al., 2006). Therefore, nutrient regeneration is related to the abundance and location of bivalves in a system. The extent to which this affects overall nutrient budgets and thus primary production is related to the system flushing rate and residence time (Newell et al., 2005).

The majority of studies of bivalve effects on nutrient recycling have focused on nitrogen because this is the most common nutrient-limiting biological production in marine and estuarine systems (Arapov et al., 2010; NapiórkowskaKrzebietke, 2017). Benthic bivalves are important contributors of nitrogen (usually in the form of ammonium, $\mathrm{NH}_{4+}$ ) to both subtidal and intertidal systems (Newell et al., 2005). Nitrogen is retained within some systems through direct recycling of nitrogen from bivalves to phytoplankton. In the Marennes-Oléron culture region in France, Leguerrier et al. (2004) show that higher oyster production increased benthic-pelagic coupling, which in turn increased secondary production (in the form of meiofauna), providing food for juveniles of predatory nektonic species. Also, Mazouni (2004) demonstrates that other planktonic organisms (bacteria, ciliates, and flagellates) can act as sources of nitrogen for bivalve molluscs in the absence of suitable autotrophic phytoplankton.

Alteration in the concentration level of silica remains one of the noticeable change during the feeding and elimination process carried out by bivalves. It is however important to know that silica is a macronutrient of the class Bacillariophyceae, or the diatoms. When a bivalve consumes diatom biomass, portions of the nitrogen and phosphorus components are assimilated into bivalve tissues, and remaining portions are returned to the environment in relatively labile forms (Newell et al., 2005). Complex, organic molecules in biodeposits can be recycled rapidly by bacterial decomposition, and nitrogenous wastes in the form of ammonia and urea are available immediately for phytoplankton reuse. Silica in diatom frustules, however, can be returned to the environment in a form, the mineral opal that is only slowly remineralized under conditions found within bio-deposits (Wikfors, 2011). Thus, Bivalve mariculture can be considered efficient recyclers of nitrogen and phosphorus in the environment while the intense feeding by bivalves can be considered an activity that encourages the growth of non-diatom microalgae on recycled nitrogen 
and phosphorus. This is the process characterized as the "cultivation" of a flagellate food source by bivalve populations.

The positive and negative feedback mechanisms observed in aquatic systems as a consequence of nutrient dynamics mediated by molluscs have been the subject of numerous studies (Newell et al., 2005). Their high filtration capacity, rapid response to high levels of food (e.g. plankton), and relative permanence in aquatic systems give bivalves the ability to stabilize systems and enhance resilience to perturbations (Jackson et al., 2001). Large bivalve assemblages can regulate the abundance of phytoplankton in shallow seas and intense filtering can reduce phytoplankton bloom intensity while extending the duration of less intense blooms (Ogilvie et al., 2000). Filtration and bio-deposition of phytoplankton and other suspended materials by extensive beds of bivalves also reduce downstream transport, thereby moderating effects of excess nutrients or sedimentation in outlying waters. Thus, bivalves provide the system with a capacity to buffer against sudden perturbations

\section{Two-Way Interaction Between Bivalve Mariculture and Phytoplankton}

Phytoplankton are a key food item in bivalve mariculture, where they are naturally occurring and introduced into enclosures with the normal circulation of seawater. According to $\mathrm{Xu}$ and Yang (2007), phytoplankton are the most important food source for intertidal oyster Crassostrea gigas and mussel Mytilus galloprovincialis, as well as for the subtidal cultured scallop Chlamys farreri. However, depending on their size and habitat, bivalves utilize different fractions of phytoplankton. By analyzing fatty acid markers, Xu and Yang (2007) found that primary food sources of cultured scallop $C$. farreri were diatoms, while in a diet of oyster $C$. gigas and mussel M. galloprovincialis dinoflagellates prevailed. Nutrient-rich microalgal strains of I. galbana and some genera like Tetraselmis, Chlorella, Dunaliella, Haematococcus, Chaetoceros, Skeletonema, Thalossiosira, Navicula, Amphora are cultured widely for bivalve mariculture (Shields, 2012). Another example of the use of phytoplankton in bivalve mariculture is a conventional French approach called the greening of oysters. This includes using the diatom Haslea ostrearia to obtain a blue coloration on the gills and labial palp of oysters. This was reported to in- crease the product's market price by $40 \%$ (MullerFeuga et al., 2003).

In the case of the bivalve molluscs that are suspension-feeders and the phytoplankton that constitute a large fraction of the living component of the suspended section upon which molluscs feed, the most obvious interaction is bivalves eating phytoplankton. Increasingly, however, the reverse trophic interaction is being recognized; dissolved inorganic and organic waste compounds released by metabolically active bivalves can supply phytoplankton with nutrient and energy requirements for their growth (Newell et al., 2005). This two-way interaction can be viewed as a type of community symbiosis developed over long evolutionary timescales (Figure 3).

Also, the reef - building characteristics of some species, such as oysters, have served under natural conditions to transfer benthic organisms into the pelagic realm where they are within the primary productivity maximum near the water surface and less vulnerable to stress from siltation and hypoxia (Wikfors, 2011). Oysters have long been considered to be "ecosystem engineers" more for their reef - building activities modifying benthic habitat than for their trophic interactions, while until recently are the particle clearance and nutrient recycling activities of oysters being considered in oyster restoration efforts (Coen et al., 2007). Similarly, mussels attach to any hard substrate in the environment and then to each other, forming three - dimensional aggregations that change shape as byssal threads are formed and broken by waves and tidal currents (Dolmer 2000; Lawrie \& McQuaid, 2001).

\section{Conclusions}

The established bivalve-phytoplankton symbiosis involves phytoplankton serving as a key nutritional live feed in bivalve mariculture owing to its high amounts of phytonutrients and biologically active ingredients (fatty acids, amino acids, carotenoids, chlorophyll, vitamins, antioxidant) and bivalves serving as consumers and cultivators of phytoplankton owing to their feeding mechanism and nutrient recycling activities. Feeding with wide range of food sources bivalves directly influence not only phytoplankton community but also bacterioplankton and zooplankton communities. Bivalve mariculture can restore trophic balance between the bivalves and phytoplankton commu- 


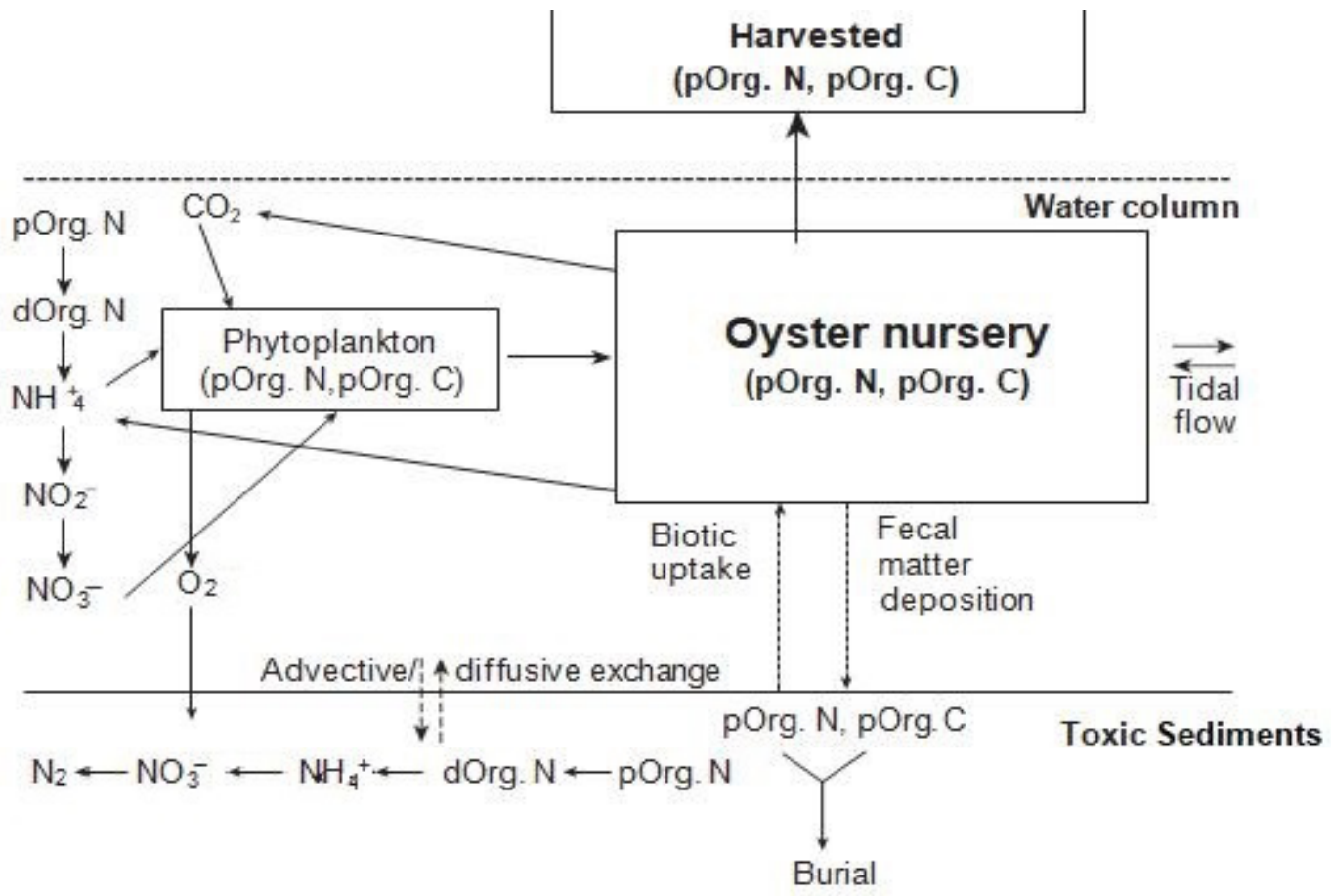

Figure 3. "Box model" of a suspension - culture, oyster nursery, with arrows depicting exchanges of carbon, nitrogen, and phosphorus between the oyster nursery and environmental compartments. Of particular note are the arrows indicating return of respiratory carbon $\left(\mathrm{CO}_{2}\right)$ and excreted nitrogen $\left(\mathrm{NH}_{4}+\right)$ to the phytoplankton community, thereby recycling resources not assimilated immediately by the oysters. (Source: Wikfors, 2011)

nities that may have existed before habitat modifications caused by human activities. The quantitative knowledge of bivalve - phytoplankton trophic interactions in coastal waters will inform bivalve mariculture development to effectively serve the needs of both seafood production and ecosystem restoration.

\section{References}

1. Arab-Tehrany E, Jacquot M, Gaiani C, Imran M, Desobry S, Linder M (2012). Beneficial effects and oxidative stability of omega-3 long-chain polyunsaturated fatty acids. Trends in Food Science \& Technology, 25(1): 24-33.

2. Arapov J, Ezgeta-Balić D, Peharda M, Ninčević Gladan Ž (2010). Bivalve feeding-how and what they eat. Ribarstvo, 68(3): 105-116.

3. Bowler C, Vardi A, Allen AE (2010). Oceanogarphic and biogeochemical insights from diatom genomes. Annual Review of Marine Sciences, 2(1): 333-365.

4. Coen LD, Brumbaugh RD, Bushek D, Grizzle R, Luckenbach MW, Posey MH, Powers SP, Tolley SG (2007). Ecosystem services related to oyster restoration. Marine Ecology Progress Series, 341: 303-307.

5. Cranford PJ, Ward JE, Shumway SE (2011). Bivalve filter feeding: variability and limits of the aquaculture biofilter. Shellfish aquaculture and the environment, Chapter 4: 81-124.
6. Delaporte M, Soudant P, Moal J, Kraffe E, Marty Y, Samain JF (2005). Incorporation and modification of dietary fatty acids in gill polar lipids by two bivalve species Crassostrea gigas and Ruditapes philippinarum. Comparative Biochemistry and Physiology. Part A, Molecular \& Integrative Physiology, 140(4): 460-470.

7. Desvilettes C, Bec A (2009). Formation and transfer of fatty acids in aquatic microbial food webs: Role of heterotrophic protists Lipids in Aquatic Ecosystems, Arts MT, Brett MT, Kainz MJ (Eds). Springer Dordrecht Heidelberg London New York, 25-43.

8. Dolmer P (2000). Feeding activity of mussels Mytilus edulis related to near - bed currents and phytoplankton biomass. Journal of Sea Research, 44(3-4): 221-231.

9. FAO (Food and Agricultural Organization of the United Nations). The State of World Fisheries and Aquaculture, (2020). URL http://www.fao.org/state-of-fisheriesaquaculture/en/. Accessed DATA.

10. Gao K, Campbell DA (2014). Photophysiological responses of marine diatoms to elevated $\mathrm{CO}_{2}$ and decreased $\mathrm{pH}$ : A review. Functional Plant Biology, 41(5): 449-459.

11. Geider RJ, La Roche J (2002). Redfield revisited: variability of $\mathrm{C}$ : N: P in marine microalgae and its biochemical basis. European Journal of Phycology 37 (1): 1-17.

12. Gladyshev MI, Arts MT, Sushchik NN (2009). Preliminary estimates of the export of omega-3 highly unsaturated fatty acids (EPA + DHA) from aquatic to terrestrial ecosystems. Lipids in Aquatic Ecosystems. Arts MT, Brett MT, Kainz MJ 
(Eds). Springer Dordrecht Heidelberg London New York, 8: 179-209.

13. Gofas S (2012). A new species of Bornia (Bivalvia: Galeommatoidea) from southern Spain. Iberus, 30(2): 41-48.

14. Gosling EM (2003). Bivalves molluscs: Biology, Ecology and Culture. Bleckwell Publishing, Oxford, 443.

15. Heydarizadeh P, Poirier I, Loizeau D, Ulmann L, Mimouni V, Schoefs B, Bertrand M (2013). Plastids of marine phytoplankton produce bioactive pigments and lipids. Marine drugs, 11(9): 3425-3471.

16. Jackson JB, Kirby MX, Berger WH, Bjorndal, KA, Botsford LW, Bourque BJ, Hughes TP (2001). Historical overfishing and the recent collapse of coastal ecosystems. Science, 293(5530): 629-637.

17. Kovač DJ, Simeunović JB, Babić OB, Mišan AČ, Milovanović IL (2013). Algae in food and feed. Food Feed Res, 40(1): 21-31.

18. Koyande AK, Chew KW, Rambabu K, Tao Y, Chu DT, Show PL (2019). Microalgae: A potential alternative to health supplementation for humans. Food Science and Human Wellness, 8: 16-24.

19. Krylova EM (2001). Septibranchiate molluscs of the family Poromyidae (Bivalvia: Poromyoidea) from the tropical western Pacific Ocean. Tropical Deep-Sea Benthos, 22: 165-200.

20. Lawrie SM, McQuaid CD (2001). Scales of mussel bed complexity: structure, associated biota and recruitment. Journal of Experimental Marine Biology and Ecology, 257: 135-161.

21. Leguerrier D, Niquil N, Petiau A, Bodoy A (2004). Modeling the impact of oyster culture on a mudflat food web in Marennes-Oléron Bay (France). Marine Ecology Progress Series, 273: 147-162.

22. Lehane C, Davenport J (2006). A 15-month study of zooplankton ingestion by farmed mussels (Mytilus edulis) in Bantry Bay, Southwest Ireland. Estuarine, Coastal and Shelf Science, 67: 645-652.

23. Mau A, Jha R (2018). Aquaculture of two commercially important molluscs (abalone and limpet): existing knowledge and future prospects. Reviews in Aquaculture, 10(3): 611-625.

24. Mazouni N (2004). Influence of suspended oyster cultures on nitrogen regeneration in a coastal lagoon (Thau, France). Marine Ecology Progress Series, 276: 103-113.

25. McKindsey CW, Thetmeyer H, Landry T, Silvert W (2006). Review of recent carrying capacity models for bivalve culture and recommendations for research and management. Aquaculture, 261(2): 451-462.

26. Muller-Feuga A, Robert R, Cahu C, Robin J, Divanach $P$ (2003). Uses of microalgae in aquaculture. Live feeds in Marine aquaculture, 1: 253-299.

27. Napiórkowska-Krzebietke A (2017). Phytoplankton as a basic nutritional source in diets of fish. Journal of Elementology, 22(3): 831-841.

28. Narasimham KA (2005). Molluscan fisheries of India. B.R Publishing Corporation.

29. Nelson DM, Tréguer P, Brzezinski MA, LeynaetA, Quéguiner B (1995). Production and dissolution of biogenic silica in the ocean. Revised global estimates, comparison with regional data and relationship to biogenic sedimentation. Global Biogeochemical Cycles, 9: 359-372.

30. Newell RIE, Fisher TR, Holyoke RR, Cornwell JC (2005). Influence of eastern oysters on nitrogen and phosphorus regeneration in Chesapeake Bay, USA. Dame RF, and Olenin, S. (eds.), The Comparative Roles of Suspension - Feeders in Ecosystems. Springer, Dordrecht, The Netherlands, 93-120.

31. Ogilvie SC, Ross AH, James MR, Schiel DR (2000). Phytoplankton biomass associated with mussel farms in Beatrix Bay, New Zealand. Aquaculture, 181: 71-80.

32. Pachiappan P, Santhanam P, Begum A, Prasath BB (2019). An introduction to plankton. Basic and Applied Phytoplankton Biology, 1-24.

33. Pal R, Choudhury AK (2014). An introduction to phytoplanktons: diversity and ecology. New Delhi: Springer, India, pp. 138-140.

34. Romano C, Voight JR, Pérez-Portela R, Martin D (2014). Morphological and Genetic Diversity of the Wood-Boring Xylophaga (Mollusca, Bivalvia): New Species and Records from Deep-Sea Iberian Canyons. PLoS ONE, 9(7): e102887. https://doi.org/10.1371/journal.pone.0102887

35. Roy S (2018). Distributions of phytoplankton carbohydrate, protein and lipid in the world oceans from Satellite Ocean colour. Journal of the International Society for Microbial Ecology, 12(6): 1457-1472.

36. Shields RJ, Lupatsch I (2012). Algae for aquaculture and animal feeds. Technikfolgenabschätzung- Theorie und Praxis, 21(1): 23-37.

37. Taylor JD, Glover EA (2006). Lucinidae (Bivalvia) - the most diverse group of chemosymbiotic molluscs. Zoological Journal of the Linnean Society, 148(3) :421-438.

38. Terech-Majewska E, Pajdak J, Siwicki AK (2016). Water as a source of macronutrients and micronutrients for fish, with special emphasis on the nutritional requirements of two fish species: the common carp (Cyprinus carpio) and the rainbow trout (Oncorhynchus mykiss). Journal of Elementology, 21(3): 947-961.

39. Ward JE, Shumway SE (2004). Separating the grain from the chaff: particle selection in suspension-and depositfeeding bivalves. Journal of Experimental Marine Biology and Ecology, 300(1-2): 83-130.

40. Wikfors GH (2011). Shellfish aquaculture and the environment. John Wiley \& Sons. Trophic interactions between phytoplankton and bivalve aquaculture. Shumway SE (Ed.), pp. 125-133.

41. Xu Q, Yang H (2007). Food sources of three bivalves living in two habitats of Jiaozhou Bay (Qingdao, China): Indicated by lipid biomarkers and stable isotope analysis. Journal of Shellfish Research, 26(2): 1-7.

42. Yahel G, Marie D, Beninger PG, Eckstein S, Genin A (2009). In situ evidence for pre-capture qualitative selection in the tropical bivalve Lithophaga simplex. Aquatic Biology, 6: 235-246.

43. Zanzerl H (2015). The burrowing behaviour and diet of thyasirid bivalves from Bonne Bay, NL. M.Sc. Diss., Memorial University of Newfoundland, $111 \mathrm{p}$. 